\title{
Commercial Bank Ownership Structure and Risk Preference
}

\author{
Haoxuan Zhong \\ Department of Economics, School of Economics, Jinan University, Guangzhou, China \\ Email: 531519831@qq.com
}

How to cite this paper: Zhong, H.X. (2017) Commercial Bank Ownership Structure and Risk Preference. Journal of Mathematical Finance, 7, 437-444. https://doi.org/10.4236/jmf.2017.72023

Received: April 21, 2017

Accepted: May 24, 2017

Published: May 27, 2017

Copyright (C) 2017 by author and Scientific Research Publishing Inc. This work is licensed under the Creative Commons Attribution International License (CC BY 4.0).

http://creativecommons.org/licenses/by/4.0/

\begin{abstract}
Company's risk-taking behavior has a significant impact on corporate earnings' growth and the social economic development, and different ownership structure will affect the company's risk preference. In this paper, with the 25 Chinese listed banks, the empirical tests the effect of ownership structure on bank's risk preference. The result showed that the correlation between ownership concentration and the bank's risk preference is positive; the bank's risk preference and shareholding separation have inverted u-shaped relation; the correlation between bank's equity balance and the bank's risk preference is negative; the correlation between bank's cash flow rights and voting rights divergence and the bank's risk preference is in inverted u-shaped.
\end{abstract}

\section{Keywords}

The Corporate Governance Structure, Ownership Structure, Risk Preference

\section{Introduction}

From a broad perspective, risk preference refers to the amount of risk that an enterprise is willing to accept in the process of achieving its objectives. It is based on the concept of risk tolerance, but risk preference explains the condition that people get positive effects when they take risks. Risk preference received special attention from the academia, business and policy department in recent years. In early studies, Litov L., Yeung B. [1] believed that the company's risk bearing or risk-taking has improved corporate earnings' growth and promoted economic development. However, if most of the participants on the market have high risk preference, it's likely to have the bad economic consequences. Many media said that the US financial crisis was due to that market participants improve the preference for risk in the pursuit of profits. In particular, most of scholars agree that misaligned incentives led to excessive risk-taking. 
For a long time, as the important content of corporate governance, many scholars studied the relationship between ownership structure and the corporate performance. However, until recently, scholars began to study the relationship between ownership structure and company risk preference. Low [2]'s research showed as the basic driving force on improving corporate performance and growth ability, risk-taking is very important to the company's business and development. However, the mainstream research involves creditors protection level, the state system, the corporate governance mechanism, social and cultural factors, and in these aspects China has bigger difference with Europe, United States and other western countries. So it is necessary to have some related research in the Chinese situation.

There are five parts in this paper. The first part is introduction, it defines the risk preference, introduces the research background and this paper's significance. The second part is literature review and research hypothesis, it introduces the research background and makes four hypothesis based on theoretical analysis. The third part empirical analysis, I set up 8 equations to check correctness of the hypothesis through empirical analysis. The last part is conclusions, the empirical conclusions are summarized, the limitation of this research and further research are showed in this part.

\section{Literature Review and Research Hypothesis}

\subsection{Literature Review}

As for the influence of ownership structure on the bank's risk preference, the results of all research are different. But on the basic of this topic, Laeven and Levine [3] found out that bank's ownership structure is very important to the bank risk-taken behavior. In their research, they focused on conflicts between bank managers and owners over risk. The result shows that bank has agent problems. The management behavior of the shareholders in the company has a great influence on the risk preference of the company. They also discussed the relationship between the risk of banks and capital regulation, deposit insurance system. They also found that banks with different ownership structure have different effect from same regulation, so they concluded that the bank's ownership structure is the most important factors affecting the bank risk-taken behavior.

Since bank ownership structure may affect the risk preference, we should find out that they have positive correlation or negative correlation. Some scholar believed that company with larger shareholder tend to be more conservative. Paligorova [4] made a detailed research about the enterprise risk-taken factors with the sample data of a large number of countries. The result shows that shareholders with large equity tend to have more conservatived investment strategy, so their own assets have stable value. Iannotta et al. [5] analyzes the data of 181 Banks from European countries from 1994 to 2004 as samples, the empirical results showed that the bank equity concentration did not change the profitability of the Banks significantly, but higher ownership concentration can improve the quality of bank's loan, so as to reduce the risk of bank assets and the risk of 
bankruptcy. Jensen et al. [6] found that in the company of equity concentration, the big shareholders' wealth is relatively concentrated, compared to the company with higher equity dispersion degree.

The other scholars believe that risk preference of a company would be higher if the ownership concentration of this company is in a high level. Anderson et al. [7] studied the relationship between ownership structure and bank risk. Through empirical research, they found out that shareholders can withstand greater risk than the business managers. It is more obvious in the case of financial deregulation.

\subsection{Research Hypothesis}

Although big shareholders may supervise managers' behavior to protect their own interests and the interests of the company, But when the proportion of large shareholders is higher, big shareholders will have stronger control. In order to obtain higher yields, they will chose high-risk investment projects to achieve high return, so as to increase the risk of the bank. Based on this discussion, the following hypotheses are advanced.

H1: Correlation between ownership concentration and the bank's risk preference is positive

Along with the rising equity dispersion, the bank may has no relatively controlling shareholders, then the operator agent problems emerged. Under the dispersed ownership structure, individual shareholder does not have enough voting rights to control the company. The enterprise actually run by the management whom does not own any property operation. Management not only focus on corporate profits, but also focus on non-monetary income such as the honorary status. Under the condition of the agent and the principal's interests are not consistent, management may take a conservative investment strategy to maintain its status. Konishi et al. [8] used recent data from Japan to study risk-taking behavior of commercial banks. They found out that the relationship between the stable shareholders' ownership and bank risk is nonlinear. Based on this discussion, the following hypotheses are advanced.

$\mathrm{H} 2$ : The bank's risk preference and shareholding separation have inverted u-shaped relation

According to the above analysis bout the ownership concentration's influence on bank's risk preference, bank's risk taken will raise when the controlling shareholder's control increase. The higher risk investment decision of controlling shareholders will be limited because of the existence of equity balances. Based on this discussion, the following hypotheses are advanced.

H3: The correlation between bank's equity balance and the bank's risk preference is negative.

When the separation of two rights is in low level, the controlling shareholder's actual benefit and real risks is roughly equal, which means that, the controlling shareholders takes the main risk of the company. In this case, controlling shareholders would give up high-risk projects to avoid huge losses. 
When the separation of two rights is in high level, the controlling shareholder could use the information asymmetry to misappropriate the interests of small and medium-sized shareholders. Based on this discussion, the following hypotheses are advanced.

H4: The correlation between bank's cash flow rights and voting rights divergence and the bank's risk preference is in inverted u-shaped.

\section{Empirical Analysis}

\subsection{Sample Selection and Data Sources}

The data come from the WIND database. WIND is the market leader in China's financial information services industry, similar to Bloomberg in USA.I selected listed banks in China as research sample, disclosed from 2006 to 2015, totally 10 years. The listed banks are Construction Bank of China, Bank of China, Agricultural Bank of China, Industrial and Commercial Bank of China, Bank of Communication, China Minsheng Banking, China Merchants Bank, China Industrial Bank, Bank of Beijing, China Everbright Bank, China CITIC Bank, Shanghai Pudong Development Bank, Hua Xia Bank, Ping An Bank, Bank of Nanjing, Bank of Ningbo, Rural Commercial Bank of Zhangjiagang, Bank of Hangzhou, Bank of Guiyang, Bank of Shanghai, Wuxi Rural Commercial Bank, Bank of Jiangsu, Jiangyin Rural Commercial Bank, Changshu Rural Commercial Bank, Bank of Shanghai and Wujiang Rural Commercial Bank.Stata12.0 is used in the empirical analysis.

\subsection{Model Setting}

\subsubsection{Variable Definition}

Table 1 shows the variable we choose. We use the rate of Risk-weighted Assets (RWA), which widely used in previous studies.

We use the shareholding ratio of first major shareholder as the ownership concentration ratio's explaining variable. Base of kroll [9]'s research, we use $D=\sum_{i=1}^{10} S i \ln (1 / S i)$ as the ownership dispersion ratio's explaining variable. At

Table 1. Variable index.

\begin{tabular}{clc}
\hline Variable Name & \multicolumn{1}{c}{ Variable Definition } & Type \\
\hline WRA & The rate of Risk-weighted Assets & Explained Variable \\
T & The shareholding ratio of first major shareholder & Explaining Variable \\
S & The ownership dispersion ratio & Explaining Variable \\
B & The equity balance degree & Explaining Variable \\
SE & Two rights separation & Explaining Variable \\
L & The rate of bank's loan & Control Variable \\
SC & The bank scale & Control Variable \\
GDP & The growth rate of Chinese GDP & Control Variable \\
M2 & The growth rate of Chinese M2 & Control Variable \\
\hline
\end{tabular}


last, we use the ratio of the sum of the second to tenth largest shareholder and first shareholder as the equity balance degree's explaining variable.

We use the bank scale, the rate of bank's loan, the growth rate of GDP, the growth rate of $\mathrm{M} 2$ as control variable.

Table 2 shows the statistical description of each variable. As we can see in Table 2, ownership structure and WRA vary among different banks.

\subsubsection{Empirical Model}

We have twice regressions on each explaining variable to see if there is nonlinear relationship between explained variable and explaining variable.

$$
\begin{aligned}
& \mathrm{F}=\alpha_{0}+\alpha_{1} \mathrm{~T}+\alpha_{2} \mathrm{~L}+\alpha_{3} \mathrm{SC}+\alpha_{4} \mathrm{GDP}+\alpha_{5} \mathrm{M} 2+\varepsilon \\
& \mathrm{F}=\alpha_{0}+\alpha_{1} \mathrm{~T}+\alpha_{2} \mathrm{~T}^{2}+\alpha_{3} \mathrm{~L}+\alpha_{4} \mathrm{SC}+\alpha_{5} \mathrm{GDP}+\alpha_{6} \mathrm{M} 2+\varepsilon \\
& \mathrm{F}=\alpha_{0}+\alpha_{1} \mathrm{~S}+\alpha_{2} \mathrm{~L}+\alpha_{3} \mathrm{SC}+\alpha_{4} \mathrm{GDP}+\alpha_{5} \mathrm{M} 2+\varepsilon \\
& \mathrm{F}=\alpha_{0}+\alpha_{1} \mathrm{~S}+\alpha_{2} \mathrm{~S}^{2}+\alpha_{3} \mathrm{~L}+\alpha_{4} \mathrm{SC}+\alpha_{5} \mathrm{GDP}+\alpha_{6} \mathrm{M} 2+\varepsilon \\
& \mathrm{F}=\alpha_{0}+\alpha_{1} \mathrm{~B}+\alpha_{2} \mathrm{~L}+\alpha_{3} \mathrm{SC}+\alpha_{4} \mathrm{GDP}+\alpha_{5} \mathrm{M} 2+\varepsilon \\
& \mathrm{F}=\alpha_{0}+\alpha_{1} \mathrm{~B}+\alpha_{2} \mathrm{~B}^{2}+\alpha_{3} \mathrm{~L}+\alpha_{4} \mathrm{SC}+\alpha_{5} \mathrm{GDP}+\alpha_{6} \mathrm{M} 2+\varepsilon \\
& \mathrm{F}=\alpha_{0}+\alpha_{1} \mathrm{SE}+\alpha_{2} \mathrm{~L}+\alpha_{3} \mathrm{SC}+\alpha_{4} \mathrm{GDP}+\alpha_{5} \mathrm{M} 2+\varepsilon \\
& \mathrm{F}=\alpha_{0}+\alpha_{1} \mathrm{SE}+\alpha_{2} \mathrm{SE}^{2}+\alpha_{3} \mathrm{~L}+\alpha_{4} \mathrm{SC}+\alpha_{5} \mathrm{GDP}+\alpha_{6} \mathrm{M} 2+\varepsilon
\end{aligned}
$$

The Equations (1), (2) is used for researching the influence of the shareholding ratio of first shareholder on bank's risk-taking, the result may verifies $\mathrm{H} 1$. The Equations (3), (4) is used for researching the influence of the ownership dispersion on bank's risk-taking, the result may verifies H2. The Equations (5), (6) is used for researching the equity balance on bank's risk-taking, the result may verifies H3. The Equations (7), (8) is used for researching the influence of the two rights separation on bank's risk-taking, the result may verifies $\mathrm{H} 4$.

\subsection{The Empirical Results}

After empirical analysis, all the explaining variable and controlled variable have no endogenous problem. All the regressions have considered individual effect and time effect.

The regression results of the (1), (2) in Table 3 showed that the shareholding ratio of first major shareholder and the rate of Risk-weighted Assets have linear relationship. Meanwhile, the regression results of the (3), (4) in Table 3 showed that the ownership dispersion ratio and the rate of Risk-weighted Assets have

Table 2. Statistical description of each variable.

\begin{tabular}{cccccc}
\hline $\begin{array}{c}\text { Variable } \\
\text { Name }\end{array}$ & $\begin{array}{c}\text { Mean } \\
\text { Value }\end{array}$ & Median & $\begin{array}{c}\text { Standard } \\
\text { Deviation }\end{array}$ & $\begin{array}{c}\text { Minimum } \\
\text { Value }\end{array}$ & $\begin{array}{c}\text { Maximum } \\
\text { Value }\end{array}$ \\
\hline WRA & 0.573 & 0.572 & 0.058 & 0.445 & 0.728 \\
T & 25.873 & 19.725 & 17.963 & 4.81 & 67.72 \\
S & 1.687 & 1.864 & 0.45 & 0.557 & 2.291 \\
B & 2.14 & 1.8 & 1.499 & 0.25 & 7.619 \\
L & 0.501 & 0.502 & 0.067 & 0.305 & 0.655 \\
SC & 35203.6 & 13367.64 & 49289.28 & 494.593 & $2.22 \mathrm{E}+05$ \\
\hline
\end{tabular}


Table 3. The first empirical results.

\begin{tabular}{|c|c|c|c|c|}
\hline & (1) & (2) & (3) & (4) \\
\hline & F & F & F & F \\
\hline \multirow[t]{2}{*}{$\mathrm{T}$} & $0.002^{\star \star}$ & 0.004 & & \\
\hline & $(-2.34)$ & $(-1.16)$ & & \\
\hline \multirow[t]{2}{*}{$\mathrm{T}^{2}$} & & 0 & & \\
\hline & & $(-0.67)$ & & \\
\hline \multirow[t]{2}{*}{$S$} & & & -0.045 & $0.485^{\star *}$ \\
\hline & & & $(-1.10)$ & $(-2.28)$ \\
\hline \multirow[t]{2}{*}{$S^{2}$} & & & & $-0.172^{\star *}$ \\
\hline & & & & $(-2.79)$ \\
\hline \multirow[t]{2}{*}{ loan } & $0.971^{* * *}$ & $0.969^{\star * *}$ & $0.971^{* * *}$ & $0.967^{\star * *}$ \\
\hline & $(-58.46)$ & $(-58.18)$ & $(-56.13)$ & $(-60.62)$ \\
\hline \multirow[t]{2}{*}{ size } & $-0.000^{\star *}$ & $-0.000^{* *}$ & $-0.000^{* *}$ & $-0.000^{*}$ \\
\hline & $(-2.39)$ & $(-2.38)$ & $(-2.66)$ & $(-1.91)$ \\
\hline \multirow[t]{2}{*}{ _cons } & 0.005 & -0.005 & $0.136^{\star *}$ & -0.243 \\
\hline & $(-0.1)$ & $(-0.08)$ & $(-2.64)$ & $(-1.40)$ \\
\hline Time effect & controlled & controlled & controlled & controlled \\
\hline r2_w & 0.962 & 0.962 & 0.961 & 0.967 \\
\hline
\end{tabular}

Note: Coefficients marked with ${ }^{* *},{ }^{* *}$, and ${ }^{*}$ are significant at $1 \%, 5 \%$, and $10 \%$ level, respectively.

nonlinear relationship, the correlation between bank's ownership dispersion ratio and risk preference is in inverted u-shaped. To summarize, $\mathrm{H} 1$ and $\mathrm{H} 2$ have been confirmed.

And the regression results of the (5), (6) in Table 4 showed that the equity balance degree and the rate of Risk-weighted Assets have linear relationship, the correlation between them is negative. At last, the regression results of the (7), (8) in Table 4 showed that the two rights separation degree and the rate of Riskweighted Assets have nonlinear relationship, the correlation between bank's cash flow rights and voting rights divergence and the bank's risk preference is in inverted $\mathrm{u}$-shaped. To summarize, $\mathrm{H} 3$ and $\mathrm{H} 4$ have been confirmed.

\section{Conclusions}

This paper uses the data of listed banks in China from 2006 to 2015 to test whether the ownership structure has influence on bank's risk preference. The conclusions are as follows:

First of all, ownership concentration and the bank's risk preference have positive correlation. This conclusion is consistent with Leaven [3]'s research. Agency Problem will come up when the ownership concentration is in low level. Banks controlled by shareholder have higher motivation to take the risk than the banks controlled by management. 
Table 4. The second empirical results.

\begin{tabular}{|c|c|c|c|c|}
\hline & $(5)$ & (6) & (7) & (8) \\
\hline & $\mathrm{F}$ & $\mathrm{F}$ & F & $\mathrm{F}$ \\
\hline \multirow[t]{2}{*}{ B } & $-0.013^{* * *}$ & -0.018 & & \\
\hline & $(-3.31)$ & $(-0.98)$ & & \\
\hline \multirow[t]{2}{*}{$\mathrm{B}^{2}$} & & 0.001 & & \\
\hline & & $(-0.26)$ & & \\
\hline \multirow[t]{2}{*}{ SE } & & & 0 & $0.008^{*}$ \\
\hline & & & $(-0.03)$ & $(-2.1)$ \\
\hline \multirow[t]{2}{*}{$\mathrm{SE}^{2}$} & & & & $-0.000^{* *}$ \\
\hline & & & & $(-2.23)$ \\
\hline \multirow[t]{2}{*}{ loan } & $0.967^{* * *}$ & $0.967^{* * *}$ & $0.547^{* *}$ & $0.542^{* \star}$ \\
\hline & $(-56.98)$ & $(-56.78)$ & $(-2.24)$ & $(-2.24)$ \\
\hline \multirow[t]{2}{*}{ size } & $-0.000^{\star *}$ & $-0.000^{* *}$ & 0 & 0 \\
\hline & $(-2.36)$ & $(-2.34)$ & $(-1.68)$ & $(-1.69)$ \\
\hline \multirow[t]{2}{*}{ _cons } & $0.093^{* *}$ & $0.099^{*}$ & $0.330^{* *}$ & $0.332^{\star *}$ \\
\hline & $(-2.12)$ & $(-2.05)$ & $(-2.35)$ & $(-2.44)$ \\
\hline Time effect & controlled & controlled & controlled & controlled \\
\hline r2_w & 0.963 & 0.963 & 0.421 & 0.44 \\
\hline
\end{tabular}

Note: Coefficients marked with ${ }^{* * *},{ }^{* *}$, and ${ }^{\star}$ are significant at $1 \%, 5 \%$, and $10 \%$ level, respectively.

Secondly, the correlation between bank's shareholding separation and the bank's risk preference is in inverted u-shaped. A bank without the controlling shareholder will have more conservative investment strategy.

Thirdly, the correlation between bank's equity balance and the bank's risk preference is negative. Small and medium-sized shareholders will have lower motivation to take the risk than the big shareholder, so the controlling shareholder's investment strategy is limited. Then as the equity balance raises, the bank will be controlled by the management, management will has lower risk preference than the shareholders.

Finally, bank's cash flow rights and voting rights divergence and the bank's risk preference have inverted u-shaped correlation. When the two rights separation degree is higher, it's more likely to cause over-investment problems. When the two rights separation degree is in low level, the controlling shareholder takes the main risk of the bank, it will have higher risk taking preference if cash flow rights and voting rights divergence increased.

This research still has some limitation. China only have 25 listed banks, the size of this sample is not big enough. Banks in this sample were not list in the same year, this leads to the lack of data sources, or the data do not reflects the bank's true situation. Further research should expand the sample size to see if city commercial banks and private banks had the same result with the listed banks, and find how the ownership structure affects the risk preference. 


\section{References}

[1] Litov, L. and Yeung, B. (2008) Corporate Governance and Risk-Taking.

[2] Low, A. (2006) Managerial Risk-Taking Behavior and Equity-Based Compensation. Journal of Financial Economics, 92, 470-490.

[3] Laeven, L. and Levine, R. (2009) Bank Governance, Regulation and Risk Taking. Journal of Financial Economics, 93, 259-275.

[4] Paligorova, T. (2010) Corporate Risk-Taking and Ownership Structure. SSRN Electronic Journal.

[5] Iannotta, G., Nocera, G. and Sironi, A. (2007) Ownership Structure, Risk and Performance in the European Banking Industry. Journal of Banking \& Finance, 31, 2127-2149.

[6] Jensen, M. and Meckling, W. (1976) The Theory of the Firm: Managerial Behaviour, Agency Costs and Ownership Structure. Social Science Electronic Publishing, 3, 305-360.

[7] Anderson, R.C. and Fraser, D.R. (2000) Corporate Control, Bank Risk Taking, and the Health of the Banking Industry. Journal of Banking \& Finance, 24, 1383-1398.

[8] Konishi, M. and Yasuda, Y. (2004) Factors Affecting Bank Risk Taking: Evidence from Japan. Journal of Banking \& Finance, 28, 215-232.

[9] Wright, P., Kroll, M., Krug, J.A. and Pettus, M. (2007) Influences of Top Management Team Incentives on Firm Risk taking. Strategic Management Journal, 28, 81 89. https://doi.org/10.1002/smj.548

Submit or recommend next manuscript to SCIRP and we will provide best service for you:

Accepting pre-submission inquiries through Email, Facebook, LinkedIn, Twitter, etc. A wide selection of journals (inclusive of 9 subjects, more than 200 journals)

Providing 24-hour high-quality service

User-friendly online submission system

Fair and swift peer-review system

Efficient typesetting and proofreading procedure

Display of the result of downloads and visits, as well as the number of cited articles

Maximum dissemination of your research work

Submit your manuscript at: http://papersubmission.scirp.org/

Or contact jmf@scirp.org 